\title{
Kualitas Daging Sapi Bali Jantan yang Diberikan Pakan Berbasis Sawit
}

\section{(The Quality of Male Bali Cattle Meat Fed Palm Oil Base Feed)}

\author{
Krishna NH, Mariyono, Pamungkas D, Anggraeny YN \\ Loka Penelitian Sapi Potong, Jl Pahlawan 2, Grati, Pasuruan, Jawa Timur \\ krishnapakabar@gmail.com
}

\begin{abstract}
This study aimed to investigate the effect of feed based on palm oil by-products to the chemical and physical qualities of male Bali cattle meat. Fifteen male Bali Cattle were kept in individual pen for four month and divided into three groups of feed treatment. The first was feed based on palm oil byproducts (A), feed used palm oil byproduct with fattening approached (B) and fattening feed (C); at the end of the study, all the animals were slaughtered and the quality of meat was observed. The parameters on this study were chemical and physical qualities of meat, namely moisture content (MC), crude fat (CF), water holding capacity (WHC) and cooking loss (CL). The observed data were analyzed using a Completely Randomized Complete Design and followed by the Duncan's Multiple Range Test (DMRT). The feed treatments did not influence MC, WHC and CL but influenced $(\mathrm{P}<0.05)$ on FC. The highest FC was on treatment $\mathrm{C}(4.012 \%)$, it was different $(\mathrm{P}<0.05)$ with treatment $\mathrm{A}(2.340 \%)$ and $\mathrm{B}(3.12 \%)$. It was concluded that using maximum palm oil byproduct on male Bali cattle feed did not influence chemical and physical qualities of the meat except the fat content.
\end{abstract}

Key words: Palm oil by-products, meat, chemical qualities, physical qualities

\begin{abstract}
ABSTRAK
Penelitian ini bertujuan untuk mengetahui pengaruh pemberian pakan berbasis hasil samping agroindustri sawit terhadap kualitas kimia dan fisik daging sapi Bali jantan. Lima belas ekor ekor sapi Bali jantan, dipelihara dalam kandang individu selama empat bulan dibagi menjadi tiga kelompok perlakuan pakan yaitu pakan berbasis sisa hasil agroindustri sawit maksimal (A), pakan menggunakan sisa hasil agroindustri sawit dengan pendekatan kualitas nutrisi pakan penggemukan (B) dan pakan penggemukan (C); pada saat penelitian berakhir seluruh sapi disembelih dan diamati kualitas dagingnya. Parameter yang diamati adalah kualitas kimia dan fisik daging yaitu kadar air (KA), kadar lemak (KL), daya ikat air (DIA) dan susut masak (SM). Data yang diperoleh dianalisis menggunakan rancangan acak lengkap pola searah dan dilanjutkan dengan uji Duncan's multiple range test (DMRT). Perlakuan pakan tidak mempengaruhi KA, DIA dan SM, namun berpengeruh $(\mathrm{P}<0,05)$ pada KL. KL tertinggi pada perlakuan C $(4,012 \%)$ berbeda $(\mathrm{P}<0,05)$ dengan perlakuan $\mathrm{B}(2,340 \%)$ dan A $(3,129 \%)$. Disimpulkan bahwa penggunaan hasil samping sawit secara maksimal tidak mempengaruhi kualitas kimia dan fisik daging sapi kecuali kadar lemaknya.
\end{abstract}

Kata kunci: Hasil samping sawit, daging, sifat kimia, sifat fisik

\section{PENDAHULUAN}

Pemeliharaan sapi potong dengan pakan terintegrasi umumnya diarahkan pada program pengembang biakan ataupun pembesaran. Namun penyusunan ransum dengan basis hasil samping yang disusun seimbang diprediksi masih dimungkinkan untuk 
digunakan pada program penggemukan. Mariyono (2013) telah menggunakan bahan pakan dari hasil samping agroindustri $(73 \%$ dan $78 \%$ dalam konsentrat) untuk penggemukan sapi potong, mendapatkan rerata pertambahan berat badan harian sebesar $940 \mathrm{~g}$ dan $860 \mathrm{~g}$, bahkan lebih dari $1 \mathrm{~kg}$ pada sekitar minggu ke-6 pemeliharaan.

Hasil samping agroindustri sawit yang paling menonjol adalah bungkil inti sawit, merupakan bahan sumber protein dan memiliki komposisi nutrisi yang lebih baik dibandingkan dengan solid sawit dan dedak padi (Utomo \& Widjaja 2012). Potensi bungkil inti sawit menurut Mathius (2003) dapat mencapai $560 \mathrm{~kg} / \mathrm{ha}$. Bahan pakan ini cocok sebagai pakan konsentrat sapi potong, namun tidak dapat diberikan tunggal karena dapat menyebabkan gangguan saluran pencernaan.

Selain bungkil, dari segi jumlah biomas yang dihasilkan, pelepah sawit dapat digolongkan sebagai bahan pakan ruminansia yang potensial. Pohon sawit rutin dipangkas pelepahnya seiring dengan rutinitas pemanenan kelapa sawit (Ishida \& Hassan 1997) pelepah dapat digunakan sebagai hijauan/sumber serat. Dalam satu hektar lahan sawit dapat dihasilkan pelepah segar sekitar 20 ribu kg/tahun (Puastuti 2008) dan daun sebesar yang dipisahkan dari pelepah sebesar $658 \mathrm{~kg} /$ tahun (Mathius 2007).

Otot dibentuk dari komponen mikro dan makro pakan yang diasup dan diretensi dalam tubuh. Oleh karena itu kandungan nutrisi dan komposisi pakan yang berbeda akan menghasilkan kuantitas dan kualitas daging serta karkas yang bervariasi pula. Purba et al. (2012) menggunakan empat perlakuan level protein dalam pakan $(15,93 \%$; $17,52 \%$; $20,03 \%$ dan 20\%) menggunakan bahan pakan utama pelepah sawit (30,5-33\%) serta bungkil inti sawit masing-masing $47 \%$ (berdasarkan bahan kering) diberikan pada 20 ekor sapi PO dengan cara dipelet, pada akhir penelitian diperoleh persentase karkas 49,22-53,49\% tidak jauh berbeda dengan sapi yang diberikan pakan dengan konsentrat komersial (54,4\%). Pada penelitian ini diamati kualitas kimia dan fisik daging sapi Bali jantan yang dipelihara dengan pakan berbasis agro industri sawit

\section{MATERI DAN METODE}

Lima belas ekor sapi Bali jantan dengan berat badan awal 300-400 kg dan skor kondisi tubuh sekitar 5 (skala 1-9). Seluruh materi penelitian dibagi secara acak menjadi tiga kelompok perlakuan model pakan, perlakuan pertama (A) merupakan pakan sapi potong yang menggunakan hasil samping agroindustri sawit secara maksimal, pakan (B) adalah pakan hasil samping agroindustri sawit secara optimal dipadukan dengan beberpa bahan pakan yang lebih beragam sehingga kualitas nutrisinya mendekati pakan penggemukan dan pakan (C) adalah pakan sapi penggemukan sebagai kontrol positif. Pakan berbasis sawit (pertama dan kedua), hijauan pakan menggunakan pelepah sawit dan sumber protein utama adalah bungkil inti sawit.

Pakan A : Pakan berbasis hasil samping agroindustri sawit maksimal

Pakan B : Pakan menggunakan hasil samping agroindustri sawit optimal, pendekatan kualitas nutrisi pakan penggemukan

Pakan C : Pakan penggemukan

Formulasi pakan masing-masing perlakuan (berdasarkan bahan kering) beserta nilai nutriennya ditampilan pada Tabel 1.

Kandang yang digunakan adalah tipe individu (berukuran 1,25 m x 2,5 m) yang dilengkapi dengan tempat pakan dan air minum. Pakan diberikan ad-libitum terkontrol atau sekitar 3-3,5\% bobot badan ternak berdasar bahan kering pakan. Pakan diberikan 2 kali sehari yaitu pagi hari (8.00 WIB) dan sore hari pada pukul 15.00 WIB. 
Tabel 1. Komposisi bahan pakan penyusun ransum dan nilai nutrisi pakan

\begin{tabular}{lccc}
\hline \multirow{2}{*}{ Bahan pakan } & \multicolumn{3}{c}{ Komposisi pakan perlakuan (\% bahan kering) } \\
\cline { 2 - 4 } Rumput gajah & $\mathrm{A}$ & $\mathrm{B}$ & $\mathrm{C}$ \\
Daun pelepah sawit & 50 & 35 & \\
Kapur & 1 & 1 & 1 \\
Garam & 1 & 1 & 1 \\
Tetes & 5,2 & 4,5 & 4 \\
Dedak padi & 8 & 5 & 16 \\
Gaplek chips & & & 8 \\
Bungkil kopra & & 15 & 20 \\
wheat pollard & & 16 & 22 \\
Kulit kopi & & 4 & 8 \\
Bungkil inti sawit & 23 & 10 & \\
Onggok & 11 & 8 & \\
Urea & 0,8 & 0,5 & \\
\hline
\end{tabular}

Seluruh materi penelitian dipelihara selam empat bulan dan di akhir penelitian dipotong untuk diamati kualitas dagingnya. Parameter yang diamati adalah kualitas kimia daging berupa kadar air dan kadar lemak serta kualitas fisik daging (daya ikat air dan susut masak). Data hasil pengamatan kemudian dianalisis variansi menggunakan Rancangan Acak Lengkap pola searah apabila berbeda nyata dilanjutkan dengan uji Duncan's multiple range test (DMRT).

\section{HASIL DAN PEMBAHASAN}

Kandungan nutrisi dari ketiga model pakan yang disusunan dan digunakan sebagai perlakuan cukup variatif terutama pada kandungan protein kasar, serat kasar dan Total Digestibel Nutrien (TDN). Kandungan nutrisi pakan perlakuan ditampilkan pada Tabel 2.

Tabel 2. Kandungan nutrisi pakan perlakuan (\% bahan kering)

\begin{tabular}{lccc}
\hline \hline Nutrisi & Pakan A & Pakan B & Pakan C \\
\hline Bahan kering & 66,72 & 73,41 & 74,98 \\
Protein kasar & 8,04 & 12,11 & 14,04 \\
Lemak kasar & 3,69 & 4,31 & 4,76 \\
Serat kasar & 22,74 & 18,37 & 13,82 \\
Abu & 5,95 & 6,54 & 9,24 \\
NDF & 54,49 & 49,16 & 42,96 \\
TDN & 59,38 & 65,57 & 69,24 \\
\hline
\end{tabular}


Pada Tabel 2 terlihat bahwa bahan kering pakan A relatif lebih rendah dibandingkan yang lain, hal tersebut terjadi akibat penggunaan pelepah sawit yang cukup tinggi. komposisi pelepah sawit yang tinggi mengakibatkan rendahnya kandungan protein kasar dalam pakan (dan meningkatkan kandungan serat kasar dan Neutral Detergen Fiber (NDF). Sebaliknya pada pakan C, Penggantian pelepah sawit dengan rumput gajah yang lebih sedikit menjadikan kandungan protein kasar paling tinggi diantara ketiga pakan perlakuan, sekaligus menurunkan kadar serat pakan dan meningkatkan kandungan TDN pakan.

Pengamatan terhadap sifat kimia dan fisik daging hasil pemotongan materi penelitian ditampilkan pada Tabel 3.

Tabel 3. Sifat kimia dan fisik daging sapi Bali Jantan

\begin{tabular}{lccc}
\hline \hline Parameter & Pakan A & Pakan B & Pakan C \\
\hline Sifat kimia & & & \\
Kadar air (\%) & 70,3783 & 68,9913 & 70,6303 \\
Kadar lemak (\% BK) & $2,340^{\mathrm{b}}$ & $3,129^{\mathrm{ab}}$ & $4,012^{\mathrm{a}}$ \\
Sifat fisik & & & \\
Daya ikat air (\%) & 38,874 & 38,101 & 39,028 \\
Susut masak (\%) & 49,444 & 48,707 & 48,167 \\
\hline
\end{tabular}

Superskrip yang berbeda pada baris yang sama menunjukkan perbedaan antar perlakuan $(\mathrm{P}<0,005)$

Pada Tabel 3. terlihat bahwa kadar air, daya ikat air dan susut masak daging hasil pemotongan sapi Bali jantan yang telah diberikan pakan yang berlainan tidak berbeda. Nilai tersebut cenderung rendah dibandingkan hasil penelitian Ili et al. (2016) yang mengamati kadar air daging sapi bali betina afkir yang memiliki nilai antar 72,2573,94\%. Ditambahkan bahwa kadar air daging sapi bali betina afkir tidak dipengaruhi oleh nutrisi pakan dan skor kegemukan. Umur dan jenis kelamin juga tidak mempengaruhi kadar air daging sapi Bali (Agustina et al. 2017).

Browning et al. (1990) menyatakan pula bahwa kadar air daging berbanding terbalik dengan kandungan lemaknya, kandungan kedua variabel tersebut memiliki korelasi negatif yang cukup kuat. Pada Tabel 3 terlihat bahwa kadar lemak daging terendah pada perlakuan pakan A yaitu sebesar 2,340\% berturut-turut diikuti oleh pakan B dan pakan C masing-masing sebesar 3,129\% dan 4,012\%. Nilai tersebut lebih tinggi dibandingkan dengan hasil pengamatan Nusi et al. (2011) kandungan lemak daging sapi PO jantan yang diberikan pakan suplementasi undegraded protein berkisar 1,32-1,35\%. Sedikit lebih tinggi dibandingakan hasil pengamatan Sarassati \& Agustina (2015) yang mengamati kandungan lemak daging sapi Bali di supermarket, kandungan lemak daging sapi Bali sebesar 2,90 dan semakin menurun seiring lama penyimpanan di dalam lemari pembeku. Daging sapi Bali betina afkir mengandung lemak 0,92-1,23\% (Ili et al. 2016).

Kandungan lemak daging sapi Bali yang diberikan pakan $\mathrm{C}$ yang memiliki karakter tinggi protein, rendah serat dan tinggi TDN memiliki kadar lemak yang nyata lebih tinggi dibandingka pakan A yang mengandung serat tinggi dari pelepah sawit. Hal tersebut dipengaruhi oleh tingginya energi yang dikandung pakan C. Dijelaskan oleh Moreira et al. (2003) bahwa kandungan energi pakan yang tinggi akan meningkatkan deposisi lemak pada daging. 
Daya ikat air daging sapi Bali yang diamati tidak berbeda nyata antar perlakuan pakan, meskipun terlihat pada Tabel 3. bahwa pakan $\mathrm{C}$ memiliki nilai daya ikat air cenderung lebih tinggi dibandingkan dengan perlakuan lain $(39,028 \%)$ diikuti berturut turut oleh perlakuan A dan B sebesar 38,874\% dan 38,101\%. Nilai tersebut sedikit lebih tinggi dibandingkan laporan Ili et al. (2016) pada daging sapi Bali betina afkir memiliki daya ikat air antara 27,07-33,87\%. Nusi et al. (2011) melaporkan bahwa daya ikat air daging sapi PO yang diberikan pakan suplementasei undegraded protein cukup variatif dengan nilai antara $16,05 \%$ dan $25,39 \%$.

Nilai susut masak diantara tiga perlakuan pakan tidak berbeda. Namun begitu nilai susut masak terbesar dialami oleh pakan A sebesar $49,444 \%$ diikuti oleh pakan B $(48,707 \%)$ dan pakan C $(48,167 \%)$. Nilai tersebut lebih rendah dibandingkan susut masak hasil analisis Ili et al. (2016) pada sapi Bali betina afkir sebesar 33,24-38,10\%. Nilai susut masak sapi PO lebih rendah lagi yaitu antara 22,33\% dan 27,57\% (Nusi et al. 2011). Nilai susut masak ada hubungannya dengan tigginya kandungan lemak dan protein dalam daging (Browning et al. 1990).

Penggunaan hasil samping agroindustri sawit mulai optimal maupun maksimal pada sapi Bali jantan tidak mempengaruhi kandungan kadar air daging, daya ikat air dan susut masak setelah sapi dipotong. Pebedaan kandungan lemak dialami oleh pakan model penggemukan dan pakan menggunakan hasil samping agroindustri sawit maksimal. Dipandang dari harga bahan pakan non sawit dan ketersediaan biomas sawit, pemeliharaan sapi dengan mengoptimalkan kandungan sawit dalam pakan di perkebunan sawit cukup menjanjikan tanpa mengurangi kualitas kimia dan fisik daging, bahkan dapat menyediakan daging sapi rendah lemak.

\section{KESIMPULAN}

Penggunaan hasil samping agroindustri sawit secara maksimal sebagai pakan sapi Bali tidak mempengaruhi kualitas kimia daging terutama pada kadar air, daya ikat air, dan susut masaknya. Sapi yang diberikan pakan yang menggunakan hasil samping agroindustri sawit cenderung menghasilkan kualitas daging lean, yang memiliki kadar lemak rendah.

\section{DAFTAR PUSTAKA}

Agustina KK, Cahya IMRD, Widyantara GM, Swacita IBN, Dharmayudha AAGO, Rudyanto MD. 2017. Nilai gizi dan kualitas fisik daging sapi bali berdasarkan jenis kelamin dan umur. Buletin Veteriner Udayana. 9:156-163.

Ili ME, Lael HDJ, Manu AE. 2016. Pengaruh aras energi pakan dan skor kondisi tubuh terhadap produksi dan kualitas fisik daging ternak sapi bali betina afkir. J Peternakan Indonesia. 18:1-12.

Ishida M, Hassan OA. 1997. Utilization of oil palm Frond as cattle feed. JARQ. 31:41-47.

Mariyono. 2013. Penyusunan ransum sapi potong berbasis hasil samping industri sawit. Disampaikan pada kegiatan "Demo Teknik Penyusunan Ransum Sapi Berbasis Produk Samping Industri Sawit” Oleh Puslitbang Peternakan - Medan, 4 September 2013.

Mathius IW. 2007. Membedah permasalahan pakan sapi potong melalui pemanfatan produk samping industri kelapa sawit. Orasi Pengukuhan Profesor Riset Bidang Pakan dan Nutrisi Ruminansia, Bogor 31 Juli 2007. Badan Penelitian dan Pengembangan Pertanian. 
Mathius IW. 2003. Perkebunan kelapa sawit dapat menjadi basis pengembangan sapi potong. Warta Penelitian dan Pengembangan Pertanian. 25:1-4.

Moreira FB, Souza NED, Matsushita M, Prado IND, Nascimento WGD. 2003. Evaluation of carcass characteristics and meat chemicalcomposition of Bos indicus and Bos indicus $\mathrm{x}$ Bos taurus crossbred steers finished in pasture system. Braz Arch Biol Technol J. 44:609-616.

Nusi M, Utomo R, Soeparno. 2011. Pengaruh penggunaan tongkol jagung dalam complete feed dan suplementasi undegraded protein terhadap pertambahan bobot badan dan kualitas daging pada sapi peranakan ongole. Buletin Peternakan. 35:173-181.

Puastuti W. 2008. Optimasi penggunaan produk samping kelapa sawit sebagai pakan ruminansia. Prosiding Seminar Nasional Optimalisasi Hasil Samping Perkebunan Kelapa Sawit dan Industri Olahannya sebagai Pakan Ternak. Bogor (Indonesia): Pusat Penelitian dan Pengembangan Peternakan.

Purba A, Mathius IW, Ginting SP, Panjaitan FR. 2012. Pakan lengkap berbasis biomassa sawit: Penggemukan sapi lokal dan kambing kacang. Prosiding InSINas.

Utomo BN, Widjaja E. 2012. Pengembangan sapi potong berbasis industri perkebunan kelapa sawit. J Litbang Pert. 31:153-161. 